\title{
SCREENING PHYSIOLOGICAL EFFECT OF ARTEMISIA HERBA ALBA AND ALLIUM SATIVUM ON SPODOPTERA LITTORALIS (BOISD) (LEPIDOPTERA: NOCTUIDAE)
}

\author{
MAALY H.A ${ }^{1}$; HANAN M. SHAZLY ${ }^{2}$ and ABELHAKEEM M. KELANY ${ }^{3}$ \\ ${ }^{1}$ Department of Biology, Faculty of Science, University of King Abdul Aziz, \\ Jeddah, P.o.42889 Saudi Arabia, Mhali@kau.edu.sa \\ ${ }^{2,3}$ Department of Biology, Faculty of Science, University of King Abdul Aziz
}

Received: 7 August 2017; Accepted: 14 August 2017

\begin{abstract}
Artemisia herba alba and Allium sativum grow in Sinai peninsula and, Northern area of Egyptian Delta respectively. Both extracts plants were evaluated as anti-insect products in an effort to develop alternative insecticides considering the environment. The effect of Artemisia and Allium extracts on some Biological aspects as well as some digestive enzymes changes after treatment with those extracts have been studied. The results indicated that treatment the 3rd instar larvae of Spodoptera littoralis for 24hours revealed satisfactory effect in larval mortality $(50 \%)$ and significant prolongation for both larval and pupal durations. This prolongation was accompanied with a decrease in the percentage of pupation and adult emergence. Digestive enzymatic activities were pronounced on estimation of Trehalase, Invertase and Amylase manifested obvious changes in the treated larvae of Spodoptera littoralis.
\end{abstract}

Key words: Artemisia herba alba, Allium sativum, Spodoptera littoralis, Trehalase, Invertase and Amylase.

\section{INTRODUCTION}

Considerable progress has been achieved over the last two decades by producing Eco friendly bioinsecticides, However, Bioactive compound synthesis of plant extract leaves (R.Ramanibie et al., 2015). Several plant extracts or isolated active compound have been studied as a potent acute or effective insecticides (Abdel Aziz, 2007). Many plants are capable of synthesizing secondary metabolites with biological properties that are important in the control against insect pests (Mathews, 1993, Enriz et al., 2000, Calderon et al., 2001, Cepedes et al., 2001, Ganzalezcoloma et al., 2002).

Artemisia herba-alba (white wormwood) family Asteraceae is a perennial shrub that grows commonly on the steppes of Northern Africa, Arabian Peninsula, Western Asia and Southwestern Europe. It is widely used in folk medicine for its antiseptic, vermifuge and antispasmodic properties. Artemisia herba-alba is a chamaeophyte that grows to $20-40 \mathrm{~cm}$ (8-16 in). Leaves are strongly aromatic and covered with fine glandular hairs that reflect sunlight giving a grayish aspect to the shrub. The leaves of sterile shoots are grey, petiolate, ovate to orbicular in outline, whereas,

Corresponding author: Dr. ABELHAKEEM M. KELANY

E-mail address: akelany@kau.edu.sa

Present address: Department of Biology, Faculty of Science, University of King Abdul Aziz the leaves of flowering stems, more abundant in winter.

Allium sativum, family Alliaceae. Its close relatives include the onion, shallot, leek and, Garlic has been used throughout history for both culinary and medicinal purposes. The garlic plant's bulb is the most commonly used part of the plant which is originated in the Yunnan province of China. In our search for naturally occurring insecticide products the plants have become naturalized including Argentina, Egypt, France, Italy and United States. (Klayman, 1989, 1993), these compounds are phototoxic (Duke et al., 2000) in laboratory assay. For these to be practical and economical the selected species must meet some requirement such as be in cultivatable and having a potent active principle, high stability, and good yield. The plant extracts, and biocides were considered as one of most economically and ecologically suitable element in pest management (Tripathi et al., 2001).

The present study aims to clarify the effects of two extracts of both Artemisia herba alba and Allium sativum on some biological aspects and digestive enzymes (trehalase, invertase and amylase on Spodoptera littoralis).

\section{MATERIALS AND METHODS}

The leaves have been dried, each species separately normally in the shade next, they have been ground, 
using electric grinder to be ready for extracting (Table1).

\section{The extracting method:}

The organic solvent (ethyl alcohol) has been used in the extracting processes with a rate $3 / 1(\mathrm{w} / \mathrm{v})$ by mixing the solvent with $50 \mathrm{qm}$ from the plant powders (Artemisia herba alba, and Allium sativum) each separately, then the mixture to be left for 24 hours in closed flasks in a place of a shade, away of the light then, the sediments have been separated through its passing in cotton. After that, the extract has been concentrated by the circular vaporizer apparatus then, the extract have been collected each one separately in glass containers and keep in fridge at $10-5^{\circ} \mathrm{C}$ as a primary material.

\section{Biological aspects:}

Fifty newly moulted $3^{\text {rd }}$ instar larvae of Spodoptera littoralis from the stock culture reared in the laboratory under a constant tempera-ture $\left(27 \pm 5^{\circ} \mathrm{C}\right)$ and $70 \pm 5 \% \mathrm{RH}$ as described by (El Defrawi et al., 1964). Different a aqueous concentration (at least five concentrations) for each of Artemisia 3\%, 1\% and Allium 5\%, 3\% were prepared and tested against the newly $3^{\text {rd }}$ instar larvae to determine their biological aspects such as larval, pupal duration, percentages of pupation and adult emergence, using dipping technique, fresh castor oil plant leaves were dipped for about 10 seconds in each concentration for the tested extract. The leaves were left for air dryness and offered to larvae for 24 hours. Three replicates of 50 larvae of each concentration, control consisted of the same number of larvae offered leaves dipped in fauct water and allowed to dry after 24 hours of feeding on treated leaves, the larvae were provided with fresh, clean and untreated leaves of castor -oil plant until pupation. All the tested larvae were starved for a period of 4-6 hours before exposure to treated leaves to ensure rapid effects of extracts.

\section{Estimation of Enzymatic activities:}

Haemolymph samples were collected from the late of $4^{\text {th }}$ instar larvae of Spodoptera littoralis of both treated and untreated larvae, the haemolymph was collected in cold tube (on ice) coated with crystals of phenylthiourea to prevent melanization, the samples was centrifuged at 2500 r.p.m about 7 minutes at low temperature $-4 \mathrm{c}$ to remove the blood cell. After centrifugation the haemolymph was divided into small portions $\left(0.5 \mathrm{ml}\right.$ per each) and stored at $-20{ }^{\circ} \mathrm{C}$ until chemical analysis Haemolymph of untreated $4^{\text {th }}$ instar larvae were also prepared by the same method.

\section{RESULTS}

Effect of Artemisia herba alba and Allium sativum on some Biological Aspects of $3^{\text {rd }}$ in tar of $S$. littoralis.

Short- term biological activity:
Data given in Table (2) clearly show that there is a remarkable effect on development of larvae fed on concentrations of Artemisia, and Allium, which prolonged the larval and pupal duration but in different values due to the type of each plant extract,the tested plant extracts could be arranged descendingly according to both larval and pupal duration as Artemisia 3\% > Artemisia 1\% > Allium $5 \%>$ Allium $3 \%$.

\section{long - term biological activity:}

In this part of investigation pointed to evaluate the effects of the early $3^{\text {rd }}$ instar larvae of $S$. littorals which treated with the tested plant extracts on the resultant successive stages including the percentages of both pupation and adult emergence. The latent effects on both pupation and adult emergence percent which resulted from $3^{\text {rd }}$ instar larvae treated with Artemisia 3\%, Artemisia 1\%, allium 5\%, allium 3\%. The failure of pupation and adult emergence which represented one of the principal indicator of these tested plant extracts latent effects against $S$.littorals also recorded. The effects of previous extracts extended from the the treated larvae to resultant pupae and adult which presented the delayed effects of such compounds on the successive stages formed through developmental processes.

Effect of the tested plant extracts on the activities of certain specific enzymes

(carbohydrases) in the haemolymph of $4^{\text {th }}$ instar larvae of $S$. littoralis:

Carbohydrases enzymes which are commonly found in salivary secretions and regions of the digestive tract of most insect have been investigated by House (1965).

It is well known that trehalase and invertase enzymes were very important in food digestion and energy supply while Amylase was active in the digestive system. These groups of specific enzymes were very important in insect growth and development so that it was of interest to evaluate their activity level in late of $4^{\text {th }}$ instar larvae of $S$. littoralis after they were fed on castor oil leaves treated with Artemisia 1\%, 3\% and Allium 3\%, Allium 5\%.

Trehalase: The data presented Table (3) and graphically illustrated in Fig (2) showed that Artemisia 3\% and Artemisia 1\% caused a remarkable reduction in this enzyme activity reached $(17.8,8.24)$ followed by Allium 5\% where the reduction percent was (3.2). On the contrary, the minimum and slightly reduction of trehalase activity caused by allium 3\% was only (1.8) as compared to check. Trehalase has the important function for liberating glucose for energy.

Invertase: The data in the same Table and Figure indicated that Artemisia 3\% and Artemisia 1\% caused 
maximum reduction in this enzyme activity reached $(16.6,7.7)$ while, the minimum reduction due to Allium 5\%, 3\% were $(4.9,2.3)$ as compared to control.

Amylase: The data in Table (3) and Fig (1) showed that Artemisia3\%, 1\% resulted highest reduction in
Amylase enzyme activity reached to be $(19.4 \%$ and $7.9 \%$ )as check while minimum reduction percent (1.9\%) due to Allium 3\% also Allium 5\% resulted in a significant reduction in Amylase activity with $2.8 \%$ as check.

\section{Tables and figures}

Table 1: The plant species used in the study with their basic components and active ingredients.

\begin{tabular}{|c|c|c|c|c|c|}
\hline $\begin{array}{l}\text { The part of } \\
\text { plant used }\end{array}$ & $\begin{array}{c}\text { Basic components and } \\
\text { effective material }\end{array}$ & Family & Scientific name & $\begin{array}{l}\text { Common } \\
\text { name }\end{array}$ & References \\
\hline Segments' & $\begin{array}{l}\text { Volatile oil sulfuric } \\
\text { compound + Vitamin+ } \\
\text { Horomons+ antirollen }\end{array}$ & Liliaceace & Allium sativum $L$ & Garlic & $\begin{array}{l}\text { (Mohiudden } \\
\text { et al., 1987) }\end{array}$ \\
\hline Leaves & $\begin{array}{c}1,8 \text { Cineol, alpha, beta } \\
\text { thujane }+ \text { oxygenated } \\
\text { monoterpenes }\end{array}$ & Asteraceae & $\begin{array}{c}\text { Artemisia herba } \\
\text { alba }\end{array}$ & $\begin{array}{l}\text { Shieh or armoise } \\
\text { blanche }\end{array}$ & $\begin{array}{c}\text { (Yashphe et } \\
\text { al., 1987) }\end{array}$ \\
\hline
\end{tabular}

Table 2: Effect of Artemisia herba alba and Allium sativum on larval, pupal durations, pupation and adult emergence percentages of the $3^{\text {rd }}$ instar larvae of Spodoptera littoralis.

\begin{tabular}{ccccc}
\hline Compounds & Larval duration & Pupal duration & Pupation \% & Adult Emergence(\%) \\
\hline Artemisia 3\% & $13.6 \pm 1.15$ & $12.9 \pm 2.89$ & $59.3^{*}$ & $49.3 *$ \\
\hline Artemisia 1\% & $13.1 \pm 0.81$ & $11.9 \pm 1.42$ & $68.5 *$ & $61.3 *$ \\
\hline Allium 5\% & $12.2 \pm 1.1$ & $11.7 \pm .32$ & $72.8 *$ & $75.6 \mathrm{~ns}$ \\
\hline Allium 3\% & $11.4 \pm 2.23$ & $10.8 \pm 2.5$ & 88.9 & $80.43^{*}$ \\
\hline Check & $10.7 \pm 0.16$ & $10.0 \pm 0.1$ & 99.2 & 98.9 \\
$\begin{array}{l}* \rightarrow \text { significant at } \mathrm{P}<0.05 \\
\mathrm{~ns} \rightarrow \text { non-significant of } \mathrm{P}<0.05\end{array}$ & & &
\end{tabular}

Table 3: Effect of Artemisia and Allium on the haemolymph carbohydrase activity of the $3^{\text {rd }}$ instar larvae of Spodoptera littoralis.

\begin{tabular}{|c|c|c|c|c|c|c|}
\hline \multicolumn{7}{|c|}{ Mean Carbohydrases activity \# (Iu/mi) \pm S.E } \\
\hline Compound & Trehalase & $\begin{array}{c}\text { Deviation from } \\
\text { check \% }\end{array}$ & Invertase & $\begin{array}{c}\text { Deviation } \\
\text { from check\% }\end{array}$ & Amylase & $\begin{array}{c}\text { Deviation from } \\
\text { check } \%\end{array}$ \\
\hline Artemisia3\% & $18.12 \pm 1.6^{* *}$ & -17.8 & $26.12 \pm 0.4 * * *$ & -16.6 & $46.8 \pm 0.4^{* *}$ & -19.4 \\
\hline Artemisial\% & $19.81 \pm 2.2 * *$ & -8.24 & $28.8 \pm 1.2 *$ & -7.7 & $42.5 \pm 1.2 *$ & -7.9 \\
\hline Allium $5 \%$ & $20.1 \pm 0.30$ & -3.2 & $30.01 \pm 0 . .68 * *$ & -4.9 & $51.3 \pm 0.7 *$ & -2.8 \\
\hline Allium3\% & $22.4 \pm 0.2$ & -1.8 & $33.02 \pm 0.56^{*}$ & -2.3 & $53.2 \pm 0.81$ & -1.9 \\
\hline Control & $22.52 \pm 1.10$ & - & $33.62 \pm 0.70$ & - & $53.99 \pm 1.32$ & - \\
\hline
\end{tabular}




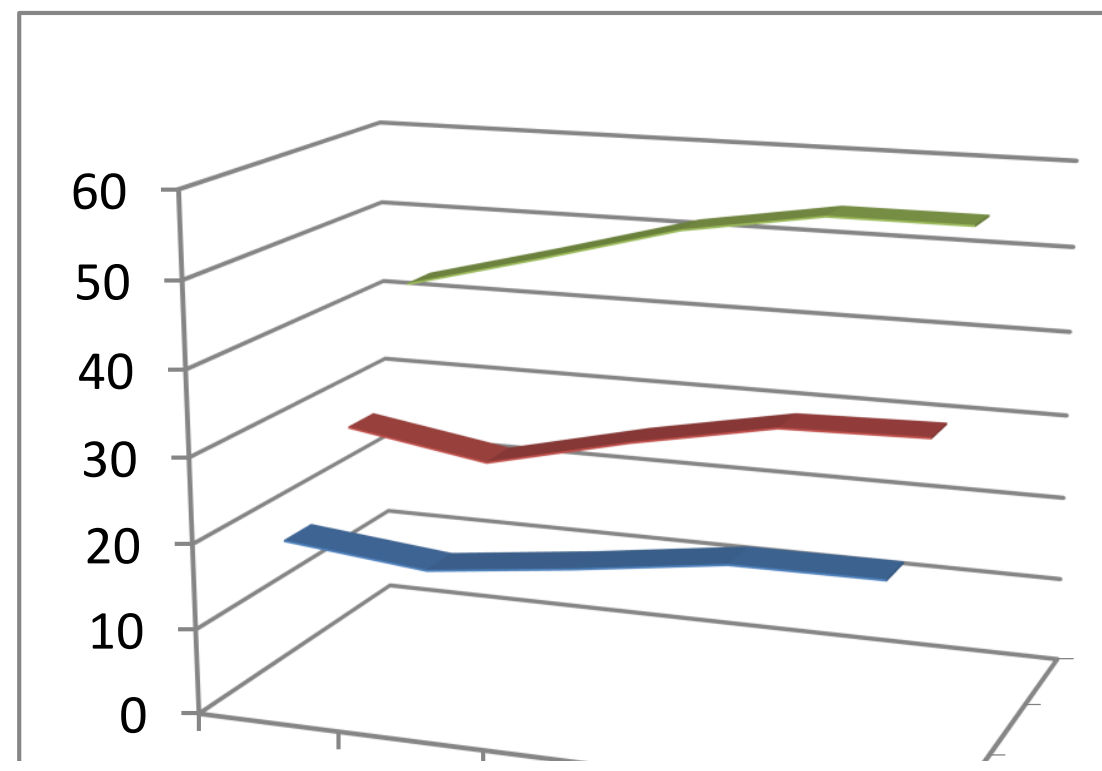

Fig. (1) Effect of Artemisia herba alba and Allium sativum on haemolymph Carbohydrase activity of the $3^{\text {rd }}$ insrar larvae of Spodoptera littoralis .

\section{DISCUSSION}

Bioassays of third- instar larvae of $S$.littoralis with Artemisia 3\%, Artemisia 1\%, Allium 3\% and 5\% Allium against the $3^{\text {rd }}$ early instar larvae of $S$. littoralis were estimated as larval, Pupal durations and corrected in the control according to Abbot (1925). As shown in Table (2) the duration of the tested larvae was highly significant increased to reach (13.6 and 13.1 days) after treatment with Artemisia $3 \%$ and $1 \%$ and significantly increased to be (12.2 and 11.4 days) for Allium sativum 5\% and 3\% respectively. Concerning the pupal duration, the data in the same Table show the same trend, were the pupal period seemed to be significantly longer than check $(10 \pm$ 0.1 ), as they were $12.9,11.9,11.7$, and 10.8 days for the tested plan extracts as the same arrangement, respectively.

The efficiency of Artemisia 3\%, 1\% and Allium 5\% and $3 \%$ caused a significant prolongation in larval and pupal durations of $3^{\text {rd }}$ instar larvae of Spodoptera littoralis (Abdel Galil et al., 2005). There was an obvious effect on the inhibition percentage of pupation and adult of the tested larvae (Manal et al., 2010). The results showed that not only the acute action was the indicator for plant extracts, but also the latent effectiveness must be taken as a parameter where the effect of tested extracts was extended to the pupae and adult ensuing from treated larvae (Kalarzyna, 2008). It could be concluded that the tested extracts resulted generally as reduction in carbohydrases enzymes with different ratios depending on the type of enzymes and extract used.

It worthy to say that carbohydrase enzymes are very important digestive enzymes which have received a great deal of attention, to be studied in order to know insects can a dap themselves to a particular type of food (Meisner et al., 1978). The rapid decrease of glucose concentration at the end of $4^{\text {th }}$ larvae of $S$. littoralis was probably caused high metabolic of the epidermis (Florkin, 1964 and Gonzalez. Coloma et al., 2002). So it is unable to utilize trehalose. However that carbohydrases (trehalase, invertase and amylase) attracted the researchers to know the digestive process in most insects (Ishaya and Swirski 1976).

\section{ACKNOWLEDGMENT}

Thanks are due to Prof. Dr. Samar rabah, Biology Department, Faculty of Science and Arts, King Abdul Aziz University for continuous help through-out the present Study.

\section{REFERENCES}

Abdel Aziz, S.E.; Omr, E.A. and Sabra, A.S. (2007): Chemical composition oc-imum americonum essential oil and its biological effect against Agrotis ipslon (lep: Noctuidae) Res. J. Agri. Bio., 3(6): 740-747.

Abdel Galil, S.A.M. and ElAswad, A.F. (2005): Antifeedant and growth inhibitory effect of tenato or triterpenoids isolated from three meliaceous species on spodoptera littoralis (boisd). J. app .sci.res., 1(2): 234-241.

Aboott, W.S. (1925): A method for computing the effectivenenss of an insecticide J. Econ. Entomol., 18-26.

Adel, N.M.; El Hawary, M.; F.M. and Adel Aziz, N.F. (2010): Some physiological, Biochemical and histological effects of Artemisia monosperma against spodoptera littoralis, Archives f 
phytopathology and plant protecting, Volume 43 , issue, No.11july.

Calderon, J.S.; Casedes, C.L.; Rosas, R.; Gomez Garibay, F.; Salzar, J.R.; Lina, L.; Arnada, E. and Kubo, I. (2001): ACetyl Cholinesterase and insect growth inhibitory activities of Gutierrezia micro Cephala on fall army worm Spodotera frugi. Perda. Z. Nalurforsh 56c: 382-394

Cespedes, C.L.; Martinez-Vazqez, M.; Calderon, J.S.; Salazar, J.R. and Arana, E. (2001): insect growth regulatory activity of some extracts and Compounds from parthenlium argentatum on fall army worm Spodoptetra frugiperda. Z. Naturforsch. 56c: 95-105.

Duke, S.O.; Romagni, F.E. and Dayan, F.E. (2000): Natural products as sources for ne mechanisms of herbicidal action. Crop prot.19: 583-589.

EL Defrawi, M.E.; ToppoZada, A.; Mans-our, M. and Zaid, M. (1964): Toxicological studies on the Egyptian cotton worm prodenin lituea $L$. different larval instar for insecticides $-\mathrm{J}$. Econ. Ent., 57: 591-593.

Enriz, R.D.; Baidon, H.A.; Zamora, M.A.; Jauregui, E.A.; Sosa, M.E.; Tonn, C.E. and Gordaliza, M. (2000): Structure antife-edant activity relationship of clerodane diterpenoids. Comparative study with anolids and azadirachtin, J. Agric. food Chem. 48: 13841392.

Florkin, M. and Jeanuiaux, C.H. (1964): Haemolymph composition. In "Physiolo-gy of Insecta": (Edited by Rockstein, M.), Vol. 3, pp. 109-152. Academic Press, New york Y London.

Gonzalez Coloma, A.; Gualano, A.; Deines, C.; Marinez Dianz, R. and Corte, Z.D. (2002): Selective action of acetogenin mitochondrial c omplex I inhibitors. Z Natur forsch. 57C:10281034.
House, H.L. (1965): Digestion. In: the Physiology of Insecta). Ed. by Rokstein, M.), 2, 815 - 858, Academic Press, New York

Ishaya, I. and Swirski, E. (1976): Trehalase, invertase and amylase activities in the black scale Saisstia oleae, and their relation to host adaptability. J. Insect physiol., 16: 1025-1029.

Klayman, D.L. (1989): Weeding out malaria. Nat. Hist. 10-26.

Klayman, D.L. (1993): Artemisia: from weed to respectable ant malarial plant, pp.242-255 in A.DKing horm and M.F. Balandrin (eds.). Human Medicinal Agents from plant, VOL. 534. ACS Symp. Series Washington, DC.

Mathews, G.A.I. and Histop, E.C. (eds.) (1993): Applicalion Technology for crop protection, Insecticide application in stores, app. 350-315, CABI, London.

Meisner, J.; Ishaaya, I.; Ascher, K.R.S. and Zur Aro, M. (1978): Gossypol inhibits protease and amylase activity of Spodoptera littoralis (Boisd.), Ann. Ent. Soc. Amer., 71 (1): 5-8.

Ramaniabai, $R$. and Velayutham, $K$. (2015): Bioactive compound synthesis of Agnanoparticles from leaves of Melia azedarach and its control for mosquito larvae. J. veternary science, volume 98: 82-88

Tripathi, A.K.; Prajapat, V.; AggarwaL, K.K. and Kum, AR.S. (2001): Toxicity, feed-ing deterrence, and effect of activity of 1, 8cienole from Artemisia annual on progeny of Tribolium Castaneum (Coleoptera :Tenebrionidae). J. Eon Entomol 94: 979-983.

Yashphi, J.; Fewersterein, I.S.; Barel, S. and Segal, $R$. (1987): The antibacterial and antispasmodic activity of Artemisia herba alba. Pharmaceutical Biology. 25: 89-99 doi: 103109.

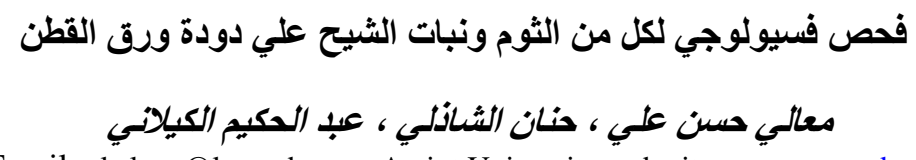

Email: akelany@kau.edu.sa Assiut University web-site: www.aun.edu.eg

اختبرت بعض المستخلصات النبااتية مثل مستخلص نبات الشيح Artemisia herba alba الذي ينمو في شبة جزيرة سيناء ونبات

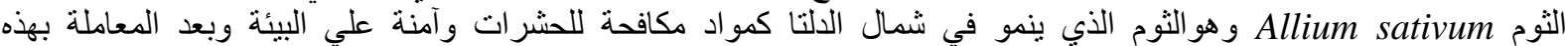

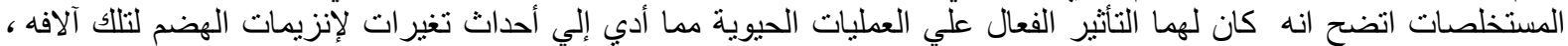

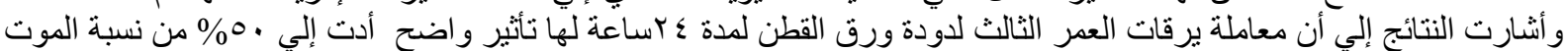

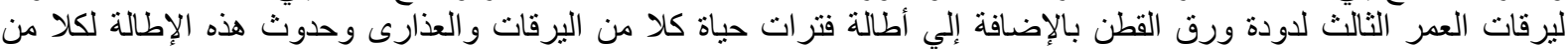

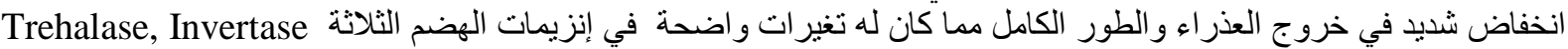
.and amylase 